\title{
Transdisciplinary research on the topic of long-term near-field monitoring of a geological repository with a view to building trust
}

\author{
Johann Arne Othmer, Karl-Heinz Lux, Ralf Wolters, and Jörg Feierabend \\ Lehrstuhl für Deponietechnik und Geomechanik, TU Clausthal, Clausthal-Zellerfeld, 38678, Germany \\ Correspondence: Johann A. Othmer (johann.arne.othmer@tu-clausthal.de)
}

Published: 10 November 2021

\begin{abstract}
Within the framework of disposal of radioactive waste in Germany, the question arises how trust in the safety of a future deep geological repository and therefore the acceptability can be increased. One aspect that could contribute to this is the option of long-term monitoring of a deep geological repository by participation of the civil society. Whether and exactly how long-term monitoring of a deep geological repository leads to more trust, is being researched in the transdisciplinary work package TRUST within the research project TRANSENS in cooperation with members of the civil society. For the transdisciplinary processing of specific repository topics, a group of 16 persons from the civil society were recruited, none of which were stakeholders with respect to the topic of repositories. This group is designated as the Working Group Civil Society (AGBe). With the help of 12 members of the AGBe a first workshop on the topic "Monitoring and trust" was carried out on 13 March 2021, supported by partners of the LUH-IRS, the TUBS-IGG and the ETH-TdLab.

This article is concerned with the preparation work, the course itself and the knowledge gained from the workshop. It deals with the preparation work in the form of a website and a report on information of the AGBe suitable for those who have been addressed, which has meant a challenge in view of the complexity of the topic of monitoring of a deep geological repository and prior knowledge of the AGBe. Furthermore, the course of the workshop, which was carried out online due to the coronavirus pandemic, is discussed, in which the 12 members of the AGBe and 10 scientists came together. The workshop began with a brainstorming on the topic of monitoring. This was followed by two specialist lectures, in which information on deep geological disposal and monitoring as well as the possibilities and limits of monitoring and monitoring conceptions was presented. The members of the AGBe were then divided into three groups, in which the central research questions of the workshop were discussed:
\end{abstract}

- Does a long-term near-field monitoring contribute to trust in the safety of deep geological disposal of radioactive waste?

- Which aspects of monitoring conceptions could increase trust in the implementation of near-field monitoring and which do not?

After the presentation of the results from the group discussion a common discussion was first carried out in the plenum, in which a picture of the sentiments within the AGBe was finally formulated.

Furthermore, the knowledge from the three discussion formats of the workshop is presented in this article. This includes the characterization of information and communication with the civil society as a central aspect in relationship with monitoring and trust. Furthermore, it showed that the AGBe views the long-term monitoring of a repository as a suitable measure for gaining trust. However, which aspects of monitoring conceptions contribute significantly to trust in the safe storage of radioactive waste is less clear after this first workshop and could not be conclusively answered.

The results of this workshop with the AGBe reflect a first impression in the discussion on monitoring and trust. As monitoring is a complex topic with many interfaces on repository storage and sealing concepts, repository 
processes and multiple physical simulations as well as on societal topics, the discussion with the AGBe on the topic of monitoring should be continued during the course of the project. Thereby, it must be taken into consideration if the first positive assesments as well as the first AGBe specific requirements regarding long-term near-field monitoring activities will change with increasing knowledge.

Kurzfassung. Im Rahmen der Entsorgung radioaktiver Abfälle in Deutschland stellt sich die Frage, wie das Vertrauen in die Sicherheit eines zukünftigen Tiefen-/Endlagers und damit auch in die Akzeptabilität eines Tiefen-/Endlagers erhöht werden kann. Ein Aspekt, der hierzu beitragen könnte, ist die Option der längerfristigen Überwachung eines Tiefen-/Endlagers unter Beteiligung der Zivilgesellschaft. Ob und wie genau die längerfristige Überwachung eines Tiefen-/Endlagers zu mehr Vertrauen führt, wird unter anderem in dem transdisziplinären Arbeitspaket TRUST in dem Forschungsprojekt TRANSENS unter Mitwirkung außerwissenschaftlicher Akteurinnen und Akteure beforscht. Für die transdisziplinäre Bearbeitung spezifischer Endlagerthemen wurde eine Gruppe bestehend aus 16 Personen der Zivilgesellschaft - alle keine Stakeholder im Hinblick auf die Thematik Endlagerung - rekrutiert. Diese Gruppe wird als Arbeitsgruppe Bevölkerung (AGBe) bezeichnet. Mithilfe von 12 Mitgliedern der AGBe wurde am 13. März 2021 ein erster Workshop zu der Thematik ,Monitoring und Vertrauen“ mit Unterstützung der Partner des LUH-IRS, des TUBS-IGG sowie des ETHTdLab durchgeführt.

Der Beitrag befasst sich mit den vorbereitenden Arbeiten, dem Ablauf und den Erkenntnissen dieses Workshops. Hierbei soll auf die vorbereitenden Arbeiten in Form einer Website und eines Berichts zur adressatengerechten Information der AGBe eingegangen werden, die angesichts der Komplexität der Thematik der Überwachung eines Tiefen-/Endlagers und des Vorwissens der AGBe eine Herausforderung dargestellt haben.

Des Weiteren wird auf den Ablauf des aufgrund der Corona-Pandemie online durchgeführten Workshops eingegangen, bei dem 12 Mitwirkende aus der AGBe und 10 Wissenschaftler zusammen kamen. Begonnen wurde der Workshop mit einem Brainstorming zu der Thematik Monitoring. Im Anschluss daran wurden 2 Fachvorträge gehalten, in denen Informationen zu Endlagerung und Monitoring, aber auch den Möglichkeiten und Grenzen von Monitoring sowie Monitoringkonzeptionen vorgestellt wurden. Hiernach wurden die Mitglieder der AGBe in 3 Kleingruppen eingeteilt, in denen anschließend die zentralen Forschungsfragen des Workshops diskutiert wurden:

- Trägt ein längerfristiges Nahfeld-Monitoring zum Vertrauen in die Sicherheit der Endlagerung radioaktiver Abfälle bei?

- Welche Aspekte von Monitoringkonzeptionen erhöhen das Vertrauen in die Durchführung eines NahfeldMonitorings - und welche nicht?

Nach der Vorstellung der Ergebnisse der Kleingruppendiskussion wurde zuletzt eine gemeinsame Diskussion im Plenum durchgeführt, in welcher ein Stimmungsbild innerhalb der AGBe zu ausgewählten Problemstellungen erfasst wurde.

Ferner sollen die Erkenntnisse aus den 3 Diskussionsformaten des Workshops in diesem Beitrag vorgestellt werden. Hierzu gehört unter anderem die Charakterisierung von Information und Kommunikation mit der Zivilgesellschaft als ein zentraler Aspekt im Zusammenhang mit Monitoring und Vertrauen. Darüber hinaus zeigte sich, dass die AGBe die längerfristige Überwachung eines Endlagers als geeignete Maßnahme zum Vertrauensgewinn ansieht. Welche Aspekte von Monitoringkonzeptionen zum Vertrauen in die sichere Endlagerung radioaktiver Abfälle beitragen, ist weniger eindeutig und nicht abschließend zu beantworten.

Dieser Workshop mit der AGBe stellt einen ersten Stand in der Diskussion um Monitoring und Vertrauen dar. Da Monitoring eine komplexe Thematik mit vielen Schnittstellen zu Endlager- und Verschlusskonzepten, Endlagerungsprozessen, multiphysikalischen Simulationen, aber auch zu gesellschaftlichen Themen ist, soll die Diskussion mit der AGBe zum Thema Monitoring im Laufe der Projektzeit fortgesetzt werden. Dabei wird zu beachten sein, wie sich die positiven Einschätzungen und Anforderungen mit zunehmendem Wissen verändern. 
Financial support. This research has been supported by the Bundesministerium für Wirtschaft und Energie (grant no. 02E11849A), the Volkswagen Foundation (grant no. 02E11849A), and the Niedersächsisches Ministerium für Wissenschaft und Kultur (grant no. 02E11849A). 